AperTO - Archivio Istituzionale Open Access dell'Università di Torino

Atypical presentation of autoimmune Iymphoproliferative syndrome due to CASP10 mutation

This is a pre print version of the following article:

Original Citation:

Availability:

This version is available http://hdl.handle.net/2318/1593281

since 2016-09-14T14:34:57Z

Published version:

DOI:10.1016/j.imlet.2016.07.001

Terms of use:

Open Access

Anyone can freely access the full text of works made available as "Open Access". Works made available under a Creative Commons license can be used according to the terms and conditions of said license. Use of all other works requires consent of the right holder (author or publisher) if not exempted from copyright protection by the applicable law. 


\title{
Atypical presentation of Autoimmune Lymphoproliferative Syndrome due to CASP10 mutation
}

\author{
Serena Ilaria Tripodi 1, Cinzia Mazza, Daniele Moratto, , Ugo Ramenghi, Roberto Caorsi, \\ Marco Gattorno, Raffaele Badolato
}

\begin{abstract}
Herein we describe a 8-years-old boy with chronic non-malignant non-infectious lymphadenopathy, failure to thrive, weakness, arthralgia, relapsing oral aftosis, and multiple non-invasive infections of the skin. Immunological and genetic studies revealed the expansion of $\mathrm{TCR} \alpha \beta^{+} \mathrm{CD} 4^{-} / \mathrm{CD} 8^{-} \mathrm{T}$ cells and a previously described heterozygous CASP10 mutation. This observation suggests that CASP10 mutations can lead to clinical manifestations that are not typical of Autoimmune lymphoproliferative syndrome.
\end{abstract}

\section{Introduction}

Autoimmune lymphoproliferative syndrome (ALPS) is a rare disorder characterized by defective FASmediated apoptotic pathway of mature lymphocytes. The typical features are chronic non-malignant enlargement of spleen and lymph nodes, autoimmune manifestations, increased risk of lymphoma and expansion of $\mathrm{TCR} \alpha \beta^{+} \mathrm{CD} 4^{-} / \mathrm{CD} 8^{-} \mathrm{T}$ cells.

Different genetic defects have been described: the majority of patients affected has a germline or somatic mutation in FAS-mediated apoptotic pathway (ALPS-FAS and ALPS-SFAS); some patients harbor FASligand mutation (ALPS-FASL) or Caspase-10 gene mutations (ALPS-CASP 10). Most of these mutations are inherited in an autosomal dominant manner. However, cases with homozygous or compound heterozygous mutations have also been reported. Some patients are clinically diagnosed, but don't present any known mutations (ALPS-U) [1,2,3,4].

Based upon the diagnostic criteria, revised in 2009 (NIH International Workshop) [4], the definitive diagnosis of ALPS needs both required criteria (chronic non-malignant, non-infectious lymphoadenopathy and/or splenomegaly and elevated TCR $\alpha \beta^{+} \mathrm{CD} 4 / \mathrm{CD} 8^{-} \mathrm{T}$ cells) and one of the primary accessory criteria (defective lymphocyte apoptotis and mutation in FAS, FASLG, CASP10)[4].

Herein we describe a patient presenting with persistent lymphadenopathy, multiple non-invasive infections, skin involvement and recurrent fever for two years, associated with weakness, muscle pain and arthralgia. 


\section{The case}

We report the case of a 8-years-old boy that came to our attention because of a recent history characterized by recurrent fever, associated with weakness, muscle pain, arthralgia, multiple episodes of oral aftosis, recurrent abdominal pain and multiple cervical lymphadenopathy. In the previous year the patient presented twice an itchy rash of the trunk and limb, which spontaneously resolved, and relapsing episodes of balanitis. His family history was not informative; constitutional delay of growth was suspected because of failure to thrive since 2 years of age.

In addition, at 18 months of age Epstein Barr virus infection was diagnosed, while molluscum contagiosum infection was observed at 4 years old. Other infectious episodes include recurrent bronchitis with wheezing, hand-foot-mouth disease, relapsing pioderma infection of the scalp and inferior limbs, multiple warts of the hands and feet and an herpes-like rash of the facial skin at 7 years of age.

The physical examination showed good general conditions, but persistent swelling of cervical lymph nodes. He performed an abdomen ultrasound, with detection of enlarged mesenteric lymph nodes persisting over 6 months, without spleen enlargement.

The laboratory tests revealed normal blood count, except for a moderate eosinophilia (about 550/uL), negative inflammatory markers, normal serum immunoglobulins and normal lymphocytes subpopulations, but increase of the TCR $\alpha \beta^{+} \mathrm{CD} 4 / \mathrm{CD}^{-} \mathrm{T}$ cells up to $3.8 \%$. Autoimmunity markers such as anti-nuclear antibodies, anti-dsDNA and ANCA were also negative (Table 1).

Because of the expansion of the TCR $\alpha \beta+\mathrm{CD}^{-} / \mathrm{CD}^{-} \mathrm{T}$ cell subset and the enlargement of multiple lymph nodes, we investigated FAS-mediated apoptosis, that turned out to be normal. Next we performed the genetic analysis of FAS, FASL, CASP10, CASP8, NRAS and KRAS genes that were associated with ALPS and ALPS-related disorders $[1,2,3,4]$.

In the patient we identified a CASP10 gene mutation: c.1216A>7 (ENST00000286186 gene sequence), resulting in aminoacid change at residue 406 (I406L). The same CASP10 mutation was identified in his mother, but the number of TCR $\alpha \beta^{+} \mathrm{CD} 4^{-} / \mathrm{CD} 8^{-} \mathrm{T}$ cells in her blood was normal (Table 1).

\section{Discussion}

Here we present the case of a patient with atypical clinical manifestations of ALPS and a CASP10 mutation, already reported in another patient, as causative of ALPS. [5].

He presents chronic, non-malignant, non-infectious cervical and mesenteric lymphadenopathy, persisting for more than 6 months, expanded $\mathrm{CD} 3^{+} \mathrm{TCR} \alpha \beta^{+} \mathrm{CD} 4^{-} / \mathrm{CD}^{-} \mathrm{T}$ cell subset, normal lymphocyte counts and heterozygous mutation of CASP10 (I406L). In addition, our patient has an history characterized by recurrent fever, associated with weakness, muscle pain, arthralgia, sometimes abdominal pain, recurrent oral aftosis, multiple non-invasive infections, especially balanitis, and recurring skin involvement.

Zhu et al. [5] have reported that the I406L mutation of CASP10, as well as another missense mutation (L285F) [6], impair apoptosis of cells transfected with the CASP10 mutant alone and confer resistance to apoptosis by a dominant negative mechanism, when cotransfected with wild-type CASP10. Other genetic 
variants of CASP10, such as V410I and I446C mutations, were classified as polymorphic variants, because were found in $3.4 \%$ and $1.6 \%$ of healthy Caucasians [5] and do not have dominant negative effect in cotransfection assays $[5,6,7,8]$.

The I406L mutation of CASP10 has been already described as causative of ALPS [5]. These patients presented lymphadenopathy, affecting mostly cervical lymph nodes, splenomegaly and autoimmune manifestations, such as autoimmune hemolytic anemia, idiopathic thrombocytopenia and malar rash exacerbated by sun. These manifestations were associated with impairment of $\mathrm{T}$ cell apoptosis, elevated immunoglobulins, appearance of autoantibodies (Coombs, anti-DNA, anti-dsDNA, anti-nuclear) and expansion of TCR $\alpha \beta^{+} \mathrm{CD} 4^{-} / \mathrm{CD} 8^{-} \mathrm{T}$ cells.

However, there is evidence that the CASP10 mutations may have incomplete penetrance, depending on the type of mutation, on possible association with mutations affecting other genes [5] and on unknown genetic and environmental modifiers. Moreover, Martinez-Feito et al. [9] have reported that genetic variations in CASP10 gene can interact with FAS gene mutations in the regulation of lymphocyte apoptosis and contribute in the determination of ALPS phenotype.

Therefore, there are many evidence suggesting that ALPS cannot be considered a typical monogenic disease, but might arise from the concurrence of multiple genetic variants, affecting genes involved in the apoptotic pathway $[9,10,11]$.

This is in accord with the broad heterogeneity of clinical manifestations among family members that share the same genotype, but mild or even absent clinical manifestations, such as mild splenomegaly, borderline cytopenias or low-titer of autoantibodies $[1,2,5]$.

Hence the clinical significance of a heterozygous mutation in a healthy relative of a patient with ALPS is yet not clear $[1,2,9]$. It's difficult to predict penetrance based on genetic mutations.

Even in our case, despite the mother of our patient has the same CASP10 mutation, she doesn't display any clinical or immunological features of the disease, including a normal number of double negative $\mathrm{T}$ cells $\left(\mathrm{TCR} \alpha \beta^{+} \mathrm{CD} 4^{-} / \mathrm{CD} 8^{-} \mathrm{T}\right.$ cells $\left.=0.5 \%\right)$.

In contrast to the report by Zhu et al., other Authors report that both $\mathrm{I} 406 \mathrm{~L}$ and L285F do not affect CASP10 activity and are not sufficient to cause the overt disease, since several mutated familial components are healthy [11].

All these controversial observations may raise the question about the relevance of this mutation in the pathogenesis of ALPS, suggesting that other environmental or genetic factors are required for the development of ALPS-related disorders, especially in patients with atypical clinical manifestations. It is likely that we need to improve our understanding about the physiopathological mechanisms beneath this syndrome, in order to enhance our clinical approach and treatment of the ALPS patients. 


\section{REFERENCES:}

[1] Madkaikar M, Mhatre S, Gupta M, Ghosh K. Advances in autoimmune lymphoproliferative syndromes. Eur J Haematol. $2011 \mathrm{Jul} ; 87(1): 1-9$.

[2] Teachey DT. New advances in the diagnosis and treatment of autoimmune lymphoproliferative syndrome. Curr Opin Pediatr. 2012 Feb;24(1):1-8.

[3] Li P, Huang P, Yang Y, Hao M, Peng H, Li F. Updated Understanding of Autoimmune Lymphoproliferative Syndrome (ALPS). Clin Rev Allergy Immunol. 2015 Feb 8.

[4] Oliveira JB, Bleesing JJ, Dianzani U, et al. Revised diagnostic criteria and classification for the autoimmune lymphoproliferative syndrome: report from the 2009 NIH International Workshop. Blood 2010;116:e35-40.

[5] Zhu S, Hsu AP, Vacek MM, Zheng L, Schäffer AA, Dale JK, Davis J, Fischer RE, Straus SE, Boruchov D, Saulsbury FT, Lenardo MJ, Puck JM. Genetic alterations in caspase-10 may be causative or protective in autoimmune lymphoproliferative syndrome. Hum Genet. 2006 Apr;119(3):284-94.

[6] Wang J, Zheng L, Lobito A, Chan FK, Dale J, Sneller M, Yao X, Puck JM, Straus SE, Lenardo MJ. Inherited human Caspase 10 mutations underlie defective lymphocyte and dendritic cell apoptosis in autoimmune lymphoproliferative syndrome type II. Cell. 1999 Jul 9;98(1):47-58

[7] Campagnoli MF, Garbarini L, Quarello P, Garelli E, Carando A, Baravalle V, Doria A, Biava A, Chiocchetti A, Rosolen A, Dufour C, Dianzani U, Ramenghi U. The broad spectrum of autoimmune lymphoproliferative disease: molecular bases, clinical features and long-term follow-up in 31 patients. Haematologica. 2006 Apr;91(4):538-41. Epub 2006 Mar 15.

[8] Grønbaek K, Dalby T, Zeuthen J, Ralfkiaer E, Guidberg P. The V410I (G1228A) variant of the caspase10 gene is a common polymorphism of the Danish population. Blood. 2000 Mar 15;95(6):2184-5.

[9] Martínez-Feito A, Melero J, Mora-Díaz S, Rodríguez-Vigil C, Elduayen R, González-Granado LI, PérezMéndez D, Sánchez-Zapardiel E, Ruiz-García R, Menchén M, Díaz-Madroñero J, Paz-Artal E, Del OrbeBarreto R, Riñón M, Allende LM. Autoimmune lymphoproliferative syndrome due to somatic FAS mutation (ALPS-sFAS) combined with a germline caspase-10 (CASP10) variation. Immunobiology. 2015 Aug 17. pii: S0171-2985(15)30044-9. doi: 10.1016/j.imbio.2015.08.004. [Epub ahead of print]

[10] Ramenghi U, Bonissoni S, Migliaretti G, DeFranco S, Bottarel F, Gambaruto C, DiFranco D, Priori R, Conti F, Dianzani I, Valesini G, Merletti F, Dianzani U. Deficiency of the Fas apoptosis pathway without Fas gene mutations is a familial trait predisposing to development of autoimmune diseases and cancer.

Blood. 2000 May 15;95(10):3176-82.

[11] Cerutti E, Campagnoli MF, Ferretti M, Garelli E, Crescenzio N, Rosolen A, Chiocchetti A, Lenardo MJ, Ramenghi U, Dianzani U. Co-inherited mutations of Fas and caspase-10 in development of the autoimmune lymphoproliferative syndrome. BMC Immunol. 2007 Nov 13;8:28. 
Table 1. Blood counts and immunological studies

\begin{tabular}{|c|c|}
\hline Blood count & \\
\hline Leucocytes & $4150 / \mathrm{uL}$ \\
\hline Neutrophils & $1370 / \mathrm{uL}$ \\
\hline Lymphocytes & $1900 / \mathrm{uL}$ \\
\hline Monocytes & 295/uL \\
\hline Eosinophils & $550 / \mathrm{uL}$ \\
\hline Erythrocytes & $4.4 \times 10^{6} / \mathrm{uL}$ \\
\hline $\mathrm{Hb}$ & $12.9 \mathrm{~g} / \mathrm{dl}$ \\
\hline $\mathrm{MCV}$ & $85.4 \mathrm{fL}$ \\
\hline Platelets & 268.000/uL \\
\hline Lymphocyte subpopulations & \\
\hline $\mathrm{CD}^{+}$ & $79.1 \%$ \\
\hline $\mathrm{CD}^{+} \mathrm{CD}^{+}$ & $27 \%$ \\
\hline $\mathrm{CD}^{+} \mathrm{CD}^{+}$ & $27.8 \%$ \\
\hline $\mathrm{CD} 19^{+}$ & $10.5 \%$ \\
\hline $\mathrm{CD}^{-} \mathrm{CD} 16^{+} \mathrm{CD}^{2} 6^{+}$ & $9.8 \%$ \\
\hline $\mathrm{CD3}^{+} \mathrm{TCR} \alpha \beta^{+} \mathrm{CD}^{-} \mathrm{CD8}^{-}$ & $3.8 \%$ \\
\hline Immunoglobulins & \\
\hline $\operatorname{Ig} \mathrm{G}$ & $1220 \mathrm{mg} / \mathrm{dl}$ \\
\hline $\operatorname{Ig} \mathrm{A}$ & $125 \mathrm{mg} / \mathrm{dl}$ \\
\hline $\operatorname{IgM}$ & $158 \mathrm{md} / \mathrm{dl}$ \\
\hline $\mathrm{IgE}$ & $131 \mathrm{KU} / 1$ \\
\hline $\begin{array}{l}\text { Anti-tetanus Antibodies } \\
\text { anti-diphtheria Antibodies }\end{array}$ & Normal response \\
\hline $\begin{array}{l}\text { Lymphocyte proliferation, } \\
\text { FAS-mediated Apoptosis }\end{array}$ & $\begin{array}{l}\text { Normal response } \\
\text { Normal response }\end{array}$ \\
\hline $\begin{array}{l}\text { Autoantibodies } \\
\text { (Anti-nuclear antibodies, } \\
\text { anti-ds DNA, ANCA) }\end{array}$ & Negative \\
\hline $\begin{array}{l}F A S, F A S L, C A S P 10, C A S P 8, \\
\text { NRAS, KRAS sequencing }\end{array}$ & $\begin{array}{l}\text { Mutation of CASP10 gene: } \\
\text { c.1216A>7 (I406L) }\end{array}$ \\
\hline
\end{tabular}

